\title{
Research on intercultural communication courses curriculum provision of foreign-related majors in higher vocational college under the concept of vocational education
}

\author{
Yan $\mathrm{Gao}^{1}$, Lei Qin ${ }^{1}$ \\ ${ }^{1}$ Shandong Foreign Languages Vocational College, Rizhao, 276826, China
}

Keywords:Vocational education; Foreign-related majors; Cross-cultural communication; Curriculum provision

\begin{abstract}
In 2006, Ministry of education documents "On the requirements of the English teaching in higher vocational education" raised the educational objective--focuses on developing communicative competence in the workplace. For foreign-related majors in higher vocational colleges, how to improve students' communicative ability with the people from different countries and cultural backgrounds is particularly urgent. This article aims at the intercultural communication courses in Shandong foreign languages vocational college, using the way of combination of stealth curriculum and dominant curriculum to set up different levels of intercultural communication courses. Promote the construction and development of intercultural communication courses and cultivate qualified talents in international working environment
\end{abstract}

\section{Inttroduction}

In 2006, the Ministry of Education proposed the teaching objective of "stressing the cultivation of communication ability under the job market environment" in Teaching Requirements for English Courses of Higher Vocational Education. With the deep implementation of international communication and cooperation, for the foreign matters-involved language major of higher vocational education "with service as the purpose and employment as the orientation", a consensus has been formed in the target positioning of higher vocational education of cultivating high-quality skill talents. To meet the requirements of the employers, the students of foreign matters-involved major in higher vocational colleges should have the ability of effective communication and exchange in the cross-cultural background, i.e. the cross-cultural communication ability. Therefore, it has been very urgent on how to implement the courses of cross-cultural communication effectively, explore how to combine the foreign language ability with the professional knowledge, achieve mastery through a comprehensive study of the subject and improve the students' ability to communicate with the individuals from different countries an with different cultural backgrounds in the foreign matters-involved work.

\section{Cross-cultural communication ability}

The communication between people on the background of heterogeneous culture is called cross-cultural communication, and this concept was proposed by American anthropologist Edward Hall in the 1960s. The cross-cultural communication ability means the diverse ability to have strong cross-cultural awareness in the heterogeneous culture environment, eliminate the cultural disturbance, identify cultural difference and realize effective communication and exchange. To cultivate the students' cross-cultural communication ability, it is not required to emphasize the language communication ability, but also stress the cultivation of students' diverse cultural awareness, cultural sensitivity and thinking, reasonably using the cross-cultural skills and avoiding the misunderstanding caused by cultural difference flexibly. 


\section{Analysis on status of opening of cross-cultural communication course in higher vocational colleges}

With Shandong Foreign Language Vocational College, Rizhao Vocational and Technical College, Liaocheng Vocational and Technical College, Weihai Vocational College, Weifang Vocational College, Zhibo Vocational College, Shandong Economic and Trade Vocational and Technical College, Shandong Business Vocational and Technical College, Shandong Foreign Trade Vocational and Technical College and Qingdao Vocational and Technical College as the main body, the author investigated and researched the opening status of cultural-course communication courses. According to the investigation result, the course opening can be concluded as the following types:

Foreign language major: most colleges open the course of foreign language and culture study in the foreign language major, for example, Korean Language Department of Shandong Foreign Language Vocational College opens the course Society and Culture of South Korea, English Education Department of Rizhao Vocational and Technical College and Shandong Foreign Language Vocational College opens the course Survey to Britain and America, Japanese Department of Shandong Foreign Language Vocational College opens the course Japanese Society and Culture, Weihai Vocational College opens the course Fundamental of Korean Culture and Business English Department of Weifang Vocational College opens the course British and American Culture, the textbooks of these courses are relatively mature, and the teaching contents have strong pertinence and practicability and emphasizes the study of course in the cross-culture cognition for students majored in foreign language, but there is still a lack of course in the cross-cultural communication skill.

Non-language foreign matters-involved major: the author mainly investigated the setting of cross-cultural courses of international economy and trade, customs declaration and international freight, tourism management, hotel management, international business, industrial and commercial enterprise management and other foreign matters-involved majors of 10 higher vocational colleges. The investigation shows that relevant majors of all investigated colleges open the course College English, but few colleges open the course on cross-cultural communication, for example, the international trade major of Shandong Foreign Language Vocational College opens the course Bilingual International Trade Affairs, industrial and commercial enterprise management major opens the course Bilingual Marketing Management, the tourism management major of Shandong Business Vocational and Technical College opens the course Tourism Social Etiquette, foreign matters-involved major of Shandong Economic and Trade College opens the course Business Etiquette, tourism management major opens the course Tourism Public Relation Etiquette, international trade affairs and customs declaration and international freight major opens the course Letter of Foreign Trade English, tourism management major of Weihai Vocational College opens the course Tourism Verbal Communication and Etiquette, international trade affairs major and customs declaration and international freight major of Weifang Vocational College opens the course Foreign Trade English, tourism management major of Zhibo Vocational College opens the courses Tourism English and Tourism Reception Etiquette, hotel management major opens the course Tourism Reception Etiquette and international business major of Shandong Foreign Language Vocational College opens the course Order Handling English, while relevant majors of other higher vocational colleges do not opens the cross-cultural communication courses. The investigation result shows that some higher vocational colleges relatively emphasize the study of bilingual courses of foreign matters-involved major and some relatively emphasize the study of cultural etiquette and foreign language courses. Although these courses play some roles in the cultivation of students' cross-cultural communication ability, it is unable to make students fully master the cross-cultural communication skills fundamentally and make them have the ability to deal with the foreign matters-involved ability in the work post. 


\section{Analysis on cross-cultural communication ability of foreign affairs-involved major of higher vocational colleges}

The author investigated of sophomores of foreign matters-involved major of Shandong Foreign Language Vocational College, totally 100 students participated in the investigation, including 50 students of English major and 50 of non-English major.

(I) Investigation mode

Questionnaire investigation is employed. The questions mainly include the difference in thinking mode, cross-cultural language and non-language communication ability, behavioral difference and value concept difference etc., which are aimed to understand the actual application ability of foreign matters-involved students in these aspects. Totally 100 questionnaires are distributed and 100 recovered, with a recovery rate of $100 \%$.

(II) Investigation result

\begin{tabular}{|c|l|c|c|c|}
\hline $\begin{array}{c}\text { Serial } \\
\text { No. }\end{array}$ & \multicolumn{1}{|c|}{ Item } & $\begin{array}{c}\text { Correct rate of } \\
\text { English major } \\
\text { students }\end{array}$ & $\begin{array}{c}\text { Correct rate of } \\
\text { non-English major } \\
\text { students }\end{array}$ & $\begin{array}{c}\text { Average } \\
\text { error rate }\end{array}$ \\
\hline 1 & $\begin{array}{l}\text { Understanding to difference } \\
\text { of thinking mode }\end{array}$ & $73 \%$ & $49 \%$ & $39 \%$ \\
\hline 2 & $\begin{array}{l}\text { Understanding to language } \\
\text { communication }\end{array}$ & $75 \%$ & $45 \%$ & $32 \%$ \\
\hline 3 & $\begin{array}{l}\text { Understanding } \\
\text { non-language } \\
\text { communication }\end{array} \quad$ to \\
\hline 4 & $\begin{array}{l}\text { Understanding to } \\
\text { behavioral difference }\end{array}$ & $56 \%$ & $46 \%$ & $49 \%$ \\
\hline 5 & $\begin{array}{l}\text { Understanding to value } \\
\text { concept difference }\end{array}$ & $65 \%$ & $53 \%$ & $41 \%$ \\
\hline
\end{tabular}

The investigation result shows that the cross-cultural communication ability of English major students is slightly stronger than that of the non-language foreign matters-involved major students, but the average error rate of questionnaires for both of them reaches about $40 \%$, overall, their cross-cultural communication ability is urgent to be strengthened.

\section{Analysis on necessity to open cross-cultural communication course in foreign matters-involved major of higher vocational colleges}

The English teaching objective of higher vocational colleges emphasizes employment orientation and competence-based education. For the students of foreign matters-involved major students, emphasis should be laid on the cultivation of students' ability to apply language to deal with the foreign matters-involved activity in the job market environment. However, currently, the English teaching of most of the higher vocational colleges emphasizes on the obtaining of English application ability certificate, the teachers mainly concern the examination training while ignoring the cultivation of students' foreign matters-involved communication ability. The reasons can be summarized as the lack of teaching contents and teaching method. According to the analysis on the cross-cultural ability of foreign matters-involved major students of the investigation target Shandong Foreign Language Vocational College, we can see that they have a relatively weak cross-cultural communication ability, however, they are a special group facing the double requirements; they should not only master English, but also work in the environment of diversified cultural background. Therefore, the English teaching to such students should include language and culture, and it is required to cultivate the students' ability of exchanging and communicating with people of different cultural backgrounds. So for the students of foreign matters-involved major in higher education colleges, it is necessary to have the cross-cultural communication ability and it is also inevitable to open such course. 


\section{Setting of cross-cultural communication course of foreign matters-involved major in higher vocational colleges}

In combination with the specific demands and ability needs of employment post of foreign matters-involved major students in higher vocational colleges, in the teaching of cross-cultural communication, for the setting mode of cross-cultural communication course of foreign matters-involved major in higher vocational colleges, it is required to establish the "two-in-one" course setting concept of explicit and implicit courses of cross-cultural communication, making the students acquire the cross-cultural communication ability, so as to cultivate the learners' cultural sensitivity and achieve the cross-cultural teaching objective of cross-cultural communication awareness.

(I) Setting of cross-cultural explicit courses

1. Open compulsory courses of cross-cultural communication. The opening of cross-cultural teaching must fully taken into account of the condition of the faculty and the students' actual condition and the cross-cultural communication courses should be set scientifically. It is suggested to open the compulsory courses of cross-cultural communication aimed at the students of foreign matters-involved major, invite teachers having the experience living abroad and experiencing cross-cultural difference in person or the foreign teachers to open such course. The specific setting of the course is as shown in the table below.

Table 1 Setting of cross-cultural communication course

\begin{tabular}{|c|c|c|c|c|c|}
\hline \multicolumn{2}{|c|}{ Target } & $\begin{array}{l}\text { Students of foreign } \\
\text { language major }\end{array}$ & $\begin{array}{l}\text { Non-language foreign } \\
\text { matters-involved major } \\
\text { students }\end{array}$ & Teachers & $\begin{array}{l}\text { Way of } \\
\text { teaching }\end{array}$ \\
\hline \multirow{5}{*}{$\begin{array}{l}\text { Course } \\
\text { type }\end{array}$} & Cognition & $\begin{array}{l}\text { Language learning; } \\
\text { international } \\
\text { business knowledge } \\
\text { training; basic } \\
\text { profile of language } \\
\text { country (etiquette } \\
\text { and custom etc.) }\end{array}$ & $\begin{array}{l}\text { Language learning; } \\
\text { international business } \\
\text { knowledge training; basic } \\
\text { profile of western culture } \\
\text { (etiquette and custom etc.) }\end{array}$ & $\begin{array}{l}\text { Foreign } \\
\text { teacher }\end{array}$ & $\begin{array}{l}\text { Fact } \\
\text { method }\end{array}$ \\
\hline & \multirow{3}{*}{ Emotion } & $\begin{array}{l}\text { Diversified culture } \\
\text { awareness training } \\
\text { course }\end{array}$ & $\begin{array}{l}\text { Diversified cultural } \\
\text { awareness training course }\end{array}$ & \multirow{4}{*}{$\begin{array}{l}\text { Teachers } \\
\text { with rich } \\
\text { cross-cultural } \\
\text { experience }\end{array}$} & \multirow{4}{*}{$\begin{array}{l}\text { Situational } \\
\text { teaching } \\
\text { approach, } \\
\text { analysis } \\
\text { method, } \\
\text { experience } \\
\text { method }\end{array}$} \\
\hline & & $\begin{array}{l}\text { Cross-cultural } \\
\text { communication } \\
\text { skill }\end{array}$ & $\begin{array}{l}\text { Cross-cultural cooperation } \\
\text { ability training course }\end{array}$ & & \\
\hline & & $\begin{array}{l}\text { International } \\
\text { business } \\
\text { communication } \\
\text { skills }\end{array}$ & $\begin{array}{l}\text { Foreign matters-involved } \\
\text { economic and trade } \\
\text { negotiation }\end{array}$ & & \\
\hline & Behavior & $\begin{array}{l}\text { Business operation } \\
\text { skill under } \\
\text { cross-cultural } \\
\text { background }\end{array}$ & $\begin{array}{l}\text { Business operation skill } \\
\text { under } \\
\text { background }\end{array}$ & & \\
\hline
\end{tabular}

2. Open arbitral selective courses of cross-cultural communication. It is suggested to open 2 to 3 cross-cultural communication elective courses to students of non-language foreign matters-involved major, which can be used for independent election by students of this major, so as to help them know about the cross-cultural knowledge and improve their cross-cultural communication ability.

The author once opened the selective course Western Etiquette Culture through pilot test among the students of International Business School and Economic Management School of Shandong Foreign Language Vocational College, with 36 class hours. During the lecturing, the author felt that the students knew little about the cross-cultural communication knowledge, and even they were unclear about the daily expressions in cross-cultural communication lime "greeting” and "calling”. 
After completion of the course, the author carried out a questionnaire investigation on the necessity to open this course, aimed to know about the students' feeling to learn such course. The investigation result shows that students selecting this course harvested a lot in the learning the course, for example, this course can expand their scope of cross-cultural knowledge, stimulate their English learning interest and is beneficial for effective exchange and communication with the westerners in the future posts. So it can be seen that the students have realized the necessity to open this course.

3. Implant the contents of cross-cultural communication into teaching of college English

According to the author's investigation, the non-language foreign matters-involved major in all higher vocational colleges opens the course College English, and teachers can integrate the language with culture consciously according to the teaching contents, and it is an effective way for students to acquire the cross-cultural communication ability to blend the cross-cultural communication contents into the course teaching.

(II) Emphasize the development of cross-cultural communication explicit courses

The cross-cultural communication explicit course is a potential course, which does not appear in the formal schedule generally, and can be realized through the cross-cultural education scene of the colleges, for example, the cross-cultural scene (college radio, and blackboard newspaper), cross-cultural interpersonal scene (mainly refers to the cross-cultural communication relation between the foreign teachers and students), cross-cultural activity scene (cross-cultural lecture activity, foreign knowledge competition, and English corner and cross-cultural TV and film activity) and cross-cultural building scene (establishment of "international park" reflecting the characteristic buildings of various countries). A good campus cross-cultural environment is beneficial for the students to form the cross-cultural quality, so as to cultivate their cross-cultural communication ability potentially.

\section{Conclusion}

The cross-cultural teaching of higher vocational college should follow the principle of "practicability dominance and application purpose”. The "vocational ability-based" cross-cultural communication course emphasizes the practicability and practice of the cross-cultural communication and focuses on the cultivation of students' cross-cultural communication ability. When setting the cross-cultural communication course, it is required to construct a cross-cultural communication course system with strong practice, and it is also possible to explore flexible and diversified course setting method according to the post demand, so as to make the students acquire the diversified cultural thinking and cross-cultural communication skills and become the professional talents of foreign matters-involved major with internationalized horizon and global awareness.

\section{Acknowledgments}

This article is the staged achievement of a planned topic of Shandong Education Science in the “Twelfth Five-year Plan" period: "Research on Current Teaching Situation of Cross-cultural Communication of Foreign Affairs-involved Major in Higher Vocational Colleges (project number: 2013GG148)

\section{References:}

[1] Spitzberg,B.H.A Model of Intercultural Communication Competence[A].In L.A.Sal'llovsr\&R.E.Porter(eds.)Intercultural $\quad$ Communication:A Reader(7th edition)[C].Wadworth,Inc.,1994:347-359.

[2] Ministry of Education, Requirements for English Course Teaching of Higher Vocational Education [Z]. Beijing: Higher Education Press, 2006.

[3] An Xiaochan, Zhou Long, Keeping up with the Times, Deepening English Course Teaching 
Reform of Higher Vocational Education- Research Report on Requirements for English Course Teaching of Higher Vocational Education [J], Foreign Language in China, 2010(4):4

[4] Zhang Yangyang, Wang Wenxiao, Implementation of Cross-cultural Communication Courses of Higher Vocational Education based on Experiential Learning [J], Journal of Henan Institute of College (social science edition), 2011(2).

[5] Gao Yan, Qin Lei, Preliminary Exploration on "Vocational Ability-based” Bilingual Teaching Mode in Foreign Language Higher Vocational Colleges [J], China Education Innovation Herald, 2010 (10) 